\title{
Insufficient amounts and inadequate distribution of dietary protein intake in apparently healthy older adults in a developing country: implications for dietary strategies to prevent sarcopenia
}

\author{
This article was published in the following Dove Press journal: \\ Clinical Interventions in Aging \\ 30 August 2013 \\ Number of times this article has been viewed
}

\section{Roxana E Ruiz Valenzuela José A Ponce Gloria Guadalupe Morales- Figueroa \\ Karina Aguilar Muro Virginia Ramírez Carreón Heliodoro Alemán-Mateo \\ Nutrition and Metabolism Department, Division of Nutrition, Research Center for Food and Development, Hermosillo, Sonora, México}

Background: Both low dietary protein intake and inadequate distribution of protein over the three mealtimes have been reported in older Caucasian adults, but the association between protein intake at each meal and muscle mass has not been studied. The purpose of this study was to evaluate dietary protein intake and distribution by mealtimes, and to explore their association with appendicular skeletal muscle mass in apparently healthy older adults.

Methods: This was a cross-sectional pilot study that included 78 people over the age of 60 years. Caloric and protein intake were estimated on the basis of three nonconsecutive 24-hour diet recalls and appendicular skeletal muscle mass by dual-energy X-ray absorptiometry.

Results: Men consumed $13.4 \mathrm{~g}$ of protein/day more than women $(P<0.05)$. The estimated value of dietary protein intake was $0.9 \mathrm{~g} / \mathrm{kg} /$ day. In this sample, $28 \%$ of subjects did not cover $100 \%$ of the dietary reference intake for protein. Lower consumption of dietary protein was found at breakfast and dinnertime compared with the recommended amount of $25-30 \mathrm{~g}(P<0.05)$. Also, the study observed that appendicular skeletal muscle mass in men and women who consumed $<25 \mathrm{~g}$ of protein at each mealtime was different from that found in the group that consumed $>25 \mathrm{~g}$ of protein at one, two, or three mealtimes.

Conclusion: While protein intake was higher than current recommendations, it failed to achieve the values reported as necessary to prevent sarcopenia. In addition, there was under-consumption of protein per mealtime, especially at breakfast and dinner.

Keywords: dietary protein intake, older adults, appendicular skeletal muscle mass

\section{Introduction}

The relative loss of muscle mass, or sarcopenia, is a new and highly prevalent clinical entity among older adults, which increases the risk of falls, reduces functionality, and contributes to mortality in this age group. ${ }^{1}$ Sarcopenia is a complex and multifactorial process. Several risk factors, such as insulin resistance, cytokines, vitamin D deficiency, sedentarism, and dietary protein intake, have been associated with the condition. ${ }^{2}$

Some studies have shown a positive association between dietary protein intake and muscle mass. Most of the epidemiologic evidence for this association comes from two cohort studies demonstrating that low dietary protein intake was significantly associated with loss of muscle mass. ${ }^{3,4}$ These studies, as well as other research, have concluded that the amount of protein recommended by the Food and Agriculture Organization of the United Nations/World Health Organization/United Nations University (FAO/WHO/ $\mathrm{UNU})$ in $1985^{5}(0.60-0.75 \mathrm{~g} / \mathrm{kg} /$ day $)$ and the requirements reanalyzed recently ${ }^{6}$
Correspondence: Heliodoro Alemán Mateo

Coordinación de Nutrición, Centro de Investigación en Alimentación y Desarrollo AC, Carretera a la Victoria $\mathrm{Km}$ 0.6, Hermosillo, Sonora, México, Apartado Postal I735, CP 83304

Tel +52 6622800094

Fax +52 6622800094

Email helio@ciad.mx 
$(0.66-0.80 \mathrm{~g} / \mathrm{kg} /$ day $)$ seem insufficient to maintain a positive balance and, therefore, a muscle mass that is compatible with good long-term health and functionality. Based on published studies of nitrogen balance, it was reported that older adults require $1.0-1.3 \mathrm{~g} / \mathrm{kg} /$ day of protein to achieve an adequate balance, ${ }^{7}$ a quantity similar to that reported of $1.2 \mathrm{~g} / \mathrm{kg} / \mathrm{day} .{ }^{4}$ This latter amount is associated significantly with $40 \%$ lower muscle mass loss compared with that associated with a protein intake of $0.8 \mathrm{~g} / \mathrm{kg} /$ day.

It is well recognized that older adults require not only a larger amount of protein, but that uniform distribution at each mealtime is determinant. It has been reported that a protein intake of $30 \mathrm{~g}$ at each meal stimulates the maximum rate of protein synthesis in both younger and older adults. Therefore, it has been suggested that intake of high quality protein foods (25-30 g) at each mealtime could prove to be a beneficial strategy in terms of increasing protein synthesis and conserving muscle mass in older adults. ${ }^{8}$ Additional evidence of the effect of high bolus protein intake comes from a recently published study ${ }^{9}$ showing that resistance exercise increased muscle protein synthesis to a greater extent when older men reached a whey protein intake of $40 \mathrm{~g}$. However, this study tested the synergistic effects of prior resistance exercise and protein feeding on muscle protein synthesis influenced by the amount of protein ingested in older men, but not in the context of increased protein intake at each mealtime.

At present, little is known about actual dietary protein intake and even less is known about protein consumption by mealtime with emphasis on prevention of sarcopenia. To our knowledge, there has only been one published study in older adults related to this issue, indicating that an important proportion of older adults did not satisfy dietary protein requirements. Also, it observed that protein consumption in the Netherlands was 8-12 g/meal, ingested mainly at breakfast and dinner, in older adults who were living in the community, others who were institutionalized, and the frail elderly. ${ }^{10}$ However, it must be noted that the study did not evaluate muscle mass, so there are no data on the impact of insufficient protein ingestion and inadequate distribution of protein over the three mealtimes on muscle mass.

The results published by the aforementioned study point out the susceptibility of older adults to insufficient consumption and inadequate distribution of dietary proteins at mealtimes. ${ }^{10}$ Also, several risk factors associated with deficient dietary protein intake are recognized, ie, reduced caloric intake, greater physical dependence, anorexia, changes in food preferences, and food insecurity, ${ }^{11}$ all factors that could be accentuated in older adults in developing countries and seriously affect their dietary protein consumption. These conditions could represent a greater risk to the development of loss of muscle mass, or sarcopenia, protein-energy wasting, and even protein-energy malnutrition. Due to the scarcity of information on populations in developing countries in relation to dietary protein intake and its implications for health, muscle mass loss, and sarcopenia prevention, this study assessed dietary protein intake and its distribution per mealtime while simultaneously exploring its association with appendicular skeletal muscle mass in apparently healthy older adults.

\section{Patients and methods Sample}

A total of 81 older adults (aged $>60$ years) were invited to participate in the study on the basis of visits to homes and retirement clubs, as well as through telephone calls and posted announcements. This was a nonprobability crosssectional study, using the following inclusion and exclusion criteria: all subjects were physically independent according to the scale of Lawton and Brody, 12 "apparently healthy" by self-reports and confirmed by the results of biochemical analyses as part of their clinical examination conducted in our institution, and with intact intellectual functioning according to the scale of Pfeiffer. ${ }^{13}$ Free of the major chronic diseases, ie, heart disease, stroke, cancer, chronic respiratory disease, and diabetes, was confirmed by their clinical histories. Volunteers were also free of any food restrictions, recent bodyweight loss, and physical disability. Finally, subjects on protein supplementation, those with a body composition exceeding the margins of the dual-energy X-ray absorptiometry (DXA) bed, and those who failed to report for any of the three 24-hour diet recall appointments were not considered in the analysis.

All volunteers received a complete explanation of the study protocol and signed the appropriate consent forms in compliance with the regulations of the ethics committee at Centro de Investigación en Alimentación y Desarrollo, AC.

\section{Study design and measurements}

This was a cross-sectional pilot study designed to explore the amount and distribution of dietary protein intake and their association with total appendicular skeletal muscle mass in community-dwelling older adults. All participants underwent a medical assessment, including biochemical analyses, body composition by DXA, anthropometry (body weight, height, waist circumference, and body mass index), and assessments of dietary protein intake by the 24 -hour diet recall method. 
The protocols for taking blood samples, evaluating body composition, and obtaining anthropometric measurements required a minimum 8 -hour fasting period. All procedures were performed by trained, standardized personnel who strictly followed the corresponding measuring techniques. The 24-hour diet recalls were performed in the volunteers' homes and in the presence of the family member in charge of the older adult's alimentation.

\section{Assessment of dietary protein intake}

Dietary ingestion was estimated on the basis of three, nonconsecutive 24-hour diet recalls. In order to control for variability in caloric intake, the 24-hour diet recalls were conducted on two weekdays and once on a weekend. Estimates of caloric and protein intake were made following a procedure published previously. ${ }^{14}$ Average caloric (kcal/day) and protein (g/day) consumption were calculated, as were the amounts of protein ingested per mealtime ( $\mathrm{g} / \mathrm{breakfast}, \mathrm{g} /$ lunch, $\mathrm{g} /$ dinner). The main protein food sources were also assessed from the 24-hour diet recall by considering average protein intake in grams in the study population, the quantity of protein provided by each food, and the frequency of their consumption. Also, a percentage of adequacy of protein intake was calculated using the following equation: protein intake/dietary reference intake $\times 100 .{ }^{15}$ In addition, protein consumption per mealtime was analyzed by forming two groups based on the recommended amounts for each mealtime (25-30 g). ${ }^{16}$ Group A included all volunteers with an intake $<25 \mathrm{~g}$ of protein at each mealtime, while group B was made up of the subjects who consumed $>25 \mathrm{~g}$ of protein during at least one mealtime.

\section{Appendicular skeletal muscle mass}

Body composition was assessed by DXA using DPX-MD+ (GE Lunar Madison, WI, USA). Measurements were carried out under fasting conditions and following established guidelines. Appendicular skeletal muscle mass was determined from whole body DXA scans as published previously. ${ }^{17}$ Appendicular skeletal muscle mass represents the sum of nonfat and nonbone tissue in both arms and legs, and is based on two assumptions, ie, lean tissue in the arms and legs represents limb skeletal muscle mass ${ }^{18}$ and limb skeletal muscle mass represents $75 \%$ of total body skeletal muscle. ${ }^{19}$

\section{Statistical analysis}

All statistical analyses were conducted with the NCSS 2004 (Number Cruncher Statistical System for Windows, Kaysville, UT, USA) using descriptive statistics for physical characteristics and a two-sample $t$-test to explore the effect of sex. Significant differences between estimated average values of daily protein consumption in the total sample were tested against the recommended daily allowance, ${ }^{20}$ the recommendation by $\mathrm{FAO} / \mathrm{WHO} / \mathrm{UNU} 1985,{ }^{5}$ and the value published by Houston et al. ${ }^{4}$ In addition, a one-sample $t$-test was applied to probe the value of protein intake per mealtime against the average recommended value of $30 \mathrm{~g} .{ }^{8,16}$ The association between appendicular skeletal muscle mass, total protein intake, and protein distribution was analyzed using a general linear model analysis of variance. Statistical significance was tested using a $P$-value of $\leq 0.05$. Variables that showed abnormal behavior were transformed logarithmically.

\section{Results}

The number of subjects included in the final sample analysis was 78 , comprising $60 \%$ women and $40 \%$ men. In the final sample, five volunteers had controlled hypertension with stable weight during the previous 6 months and no self-reported dietary modifications, so were included in the analysis. Three older adults were excluded from the study because they did not fulfill the inclusion criteria. With respect to anthropometric characteristics, men on average weighed $8.4 \mathrm{~kg}$ more than women and were $13 \mathrm{~cm}$ taller $(P<0.001)$. However, their body mass indices were not significantly different. Results of body composition analysis shows higher values for fat mass and less total lean mass and appendicular skeletal muscle mass in women compared with older men (Table 1).

With respect to protein intake, men consumed $13.4 \mathrm{~g}$ of protein/day more than women $(P<0.05)$, and protein

Table I Age and physical characteristics of older male and female subjects from northwestern Mexico ${ }^{a}$

\begin{tabular}{lllll}
\hline Variables & $\begin{array}{l}\text { Total } \\
\text { sample } \\
\mathbf{n = 7 8}\end{array}$ & $\begin{array}{l}\text { Men } \\
\mathbf{n = 3 1}\end{array}$ & $\begin{array}{l}\text { Women } \\
\mathbf{n = 4 7}\end{array}$ & P-value \\
\hline Age, years & $68.7 \pm 6.3$ & $68.3 \pm 6.16$ & $69.0 \pm 6.5$ & 0.6 \\
Body weight, $\mathrm{kg}$ & $71.4 \pm 14.0$ & $76.6 \pm 14.2$ & $67.9 \pm 12.9$ & $0.00 \mathrm{I}$ \\
Height, $\mathrm{m}$ & $1.60 \pm 0.09$ & $1.67 \pm 0.07$ & $1.54 \pm 0.05$ & $0.00 \mathrm{I}$ \\
Body mass & $27.3 \pm 4.1$ & $27.0 \pm 3.6$ & $28.2 \pm 4.4$ & 0.2 \\
index, kg/m & & & & \\
Waist & $100.9 \pm 10.3$ & $99.5 \pm 10.5$ & $101.8 \pm 11.0$ & 0.3 \\
circumference, $\mathrm{cm}$ & & & & \\
Total body fat, $\mathrm{kg}$ & $27.3 \pm 9.0$ & $23.7 \pm 6.5$ & $29.6 \pm 9.7$ & 0.002 \\
Lean tissue, $\mathrm{kg}$ & $41.0 \pm 9.9$ & $50.9 \pm 8.2$ & $34.5 \pm 3.7$ & $0.00 \mathrm{I}$ \\
ASM, kg & $18.1 \pm 4.7$ & $22.6 \pm 3.9$ & $15.1 \pm 1.78$ & $0.00 \mathrm{I}$ \\
\hline
\end{tabular}

Note: a Mean \pm standard deviation.

Abbreviation: ASM, appendicular skeletal muscle mass. 
consumption per $\mathrm{kg}$ of bodyweight, the study found that the estimated average consumption in men and women was above the recommended daily allowance and the FAO/WHO/UNU norms for proteins ( 0.99 versus $0.8 \mathrm{~g} / \mathrm{kg} /$ day, $P<0.001)$, but below the value associated with lower muscle mass loss and that suggested as being necessary to prevent sarcopenia in older adults ( 0.99 versus $1.2 \mathrm{~g} / \mathrm{kg} /$ day, $P<0.001$, Table 2$)$. Although the average protein intake was $0.99 \mathrm{~g} / \mathrm{kg} / \mathrm{day}$, $37 \%$ of subjects did not cover the recommended amount of protein $/ \mathrm{kg}$ of bodyweight $(0.8 \mathrm{~g} / \mathrm{kg} /$ day $)$.

Adequacy of protein intake was approximately 51\%-315\% of the dietary reference intake. However, $28 \%$ of the older adults failed to cover $100 \%$ of the dietary reference intake. In this regard, women were the group most severely affected. Finally, a positive association was found between caloric intake and grams of protein/day in the total sample $(r=0.82$; $P<0.001)$.

On observing protein intake per mealtime and comparing it with the recommended protein consumption of $30 \mathrm{~g}$ at each meal, our findings showed that $81 \%$ of these older adults consumed quantities below the recommended level of $30 \mathrm{~g}$ at breakfast. This under-consumption per mealtime was accentuated in the data at dinnertime, with $86 \%$ of the older adults in the sample failing to fulfill this recommendation. At both of these mealtimes, under-consumption of protein was more marked in women. Another important finding was that $3 \%$ of the total sample did not eat breakfast at all. On comparing intake between men and women, our findings revealed an effect of sex in the case of dinner (Table 2).

The main sources of protein in the total sample were meat, chicken, milk, eggs, cheese, corn tortillas, meat-filled tamales, beans, and wheat tortillas. Thus, most of the protein

Table 2 Dietary protein intake and caloric consumption by sex ${ }^{\mathrm{a}}$

\begin{tabular}{lccll}
\hline Variables & Men & Women & $\begin{array}{l}\text { Mean } \\
\text { difference }\end{array}$ & P-value \\
\hline $\begin{array}{l}\text { Caloric } \\
\text { intake, }\end{array}$ & $1,975.8 \pm 588.5$ & $1,517.2 \pm 494.1$ & -458.5 & 0.00 \\
kcal/day & & & & \\
$\begin{array}{l}\text { Protein } \\
\text { intake, }\end{array}$ & $73.4 \pm 22.8$ & $58.5 \pm 22.8$ & -14.9 & 0.007 \\
g/day & & & & \\
$\begin{array}{l}\text { Protein } \\
\text { intake }\end{array}$ & $0.99 \pm 0.37$ & $0.88 \pm 0.38$ & -0.1 & 0.18 \\
g/kg/day & & & & \\
$\begin{array}{l}\text { Dietary protein intake per mealtime, 30 g/mealtime } \\
\text { Breakfast }\end{array}$ & $18.7 \pm 10.9$ & $15.3 \pm 10.0$ & -3.3 & 0.23 \\
Lunch & $33.3 \pm 17.4$ & $26.9 \pm 15.4$ & -6.4 & 0.10 \\
$\begin{array}{l}\text { Dinner } \\
\text { Nin }\end{array}$ & $19.9 \pm 12.7$ & $14.3 \pm 7.6$ & -5.5 & 0.02 \\
\hline
\end{tabular}

Note: a Mean \pm standard deviation. consumed was due to frequent ingestion of foods supplying proteins from animal sources. It is important to note that protein intake from vegetable sources (beans, corn, wheat tortillas) contributed due to the high frequency with which they were consumed by the study population.

In relation to protein ingestion and its association with muscle mass, the study found a modest and positive association between dietary protein intake and appendicular skeletal muscle mass $(P<0.05$, Figure 1$)$. In addition, it found a significant effect of amount of protein per mealtime on muscle mass. Appendicular skeletal muscle mass $(\mathrm{kg})$ for group A differed from that of group B for men and women who consumed $>25 \mathrm{~g}$ of dietary protein $(15.9 \pm 0.9 \mathrm{~kg}$ versus $19.1 \pm 0.6 \mathrm{~kg}, P<0.01)$. However, on adjusting for bodyweight, sex, and height, the appendicular skeletal muscle mass did not prove to be significantly different between the two groups $(18.1 \pm 0.4 \mathrm{~kg}$ versus $18.1 \pm 0.2 \mathrm{~kg}, P=0.87)$.

\section{Discussion}

This is the first pilot study of a non-Caucasian population to suggest that while dietary protein intake exceeds the level of ingestion proposed in current recommendations, ${ }^{5,15,20}$ it does not achieve the values that have been associated with a lower muscle mass loss in older adults. ${ }^{4}$ Also, it indicates a possible association between low dietary protein consumption per mealtime and reduced appendicular skeletal muscle mass in this age group. These findings are important because both low protein intake and an inadequate distribution of dietary proteins (25-30 g of protein/mealtime) could lead to muscle mass loss and increase the risk of sarcopenia. ${ }^{8,16}$ The loss of appendicular skeletal muscle mass is a common problem in older adults in northwestern Mexico, with data

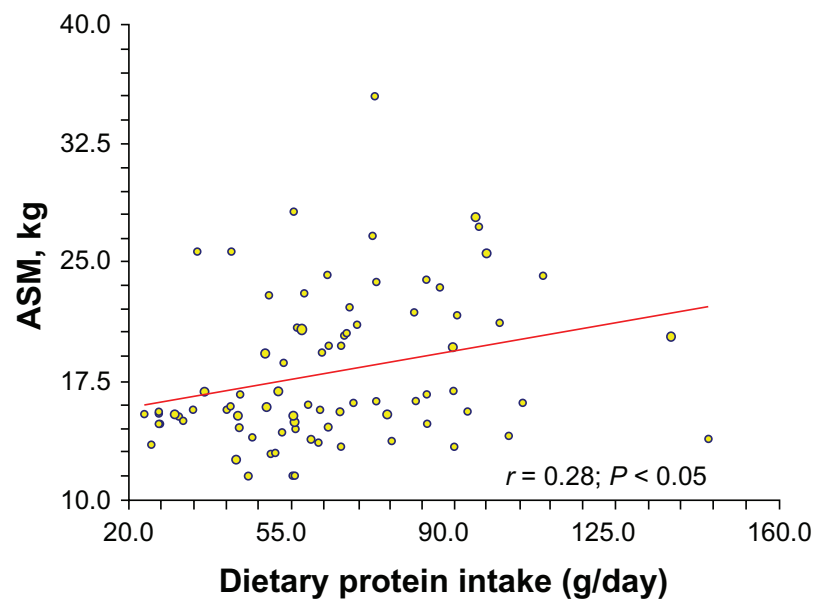

Figure I Positive association between dietary protein intake and appendicular skeletal muscle mass in older men and women subjects. Abbreviation: ASM, appendicular skeletal muscle mass. 
from previous studies showing a prevalence and incidence of this condition of $21 \%$ and $13 \%$, respectively, in persons over 60 years. $^{21}$

The results of this pilot study also show an effect of sex on total protein intake and on the amount of protein ingested at dinnertime, with women having lower indices for both total protein consumption and protein consumption at dinner $(P<0.05)$. Also, important is that a proportion of the total sample did not cover the $0.8 \mathrm{~g} / \mathrm{kg} /$ day protein intake. Once again, women were affected in this respect. This low intake of total dietary protein and of proteins ingested at dinnertime could be associated with several factors that have been implicated as principal determinants of protein intake in this age group. ${ }^{11}$

The results indicating low protein consumption in this pilot study especially among the women may be determined by their low total caloric intake compared with men (Table 2). In both men and women, this could be due to low caloric consumption estimated by the 24-hour recall method compared with total energy expenditure as measured by the double-labeled water technique in another sample of older men and women from the same community $(2,376 \pm 274 \mathrm{kcal} /$ day and $1,917 \pm 305 \mathrm{kcal} /$ day, respectively). ${ }^{22}$ However, other factors, such as anorexia, changes in food preferences, lack of access to protein-rich foods, and cultural patterns of eating a light dinner, may also be involved in this low estimated protein intake. Although the relatively small sample size may be another significant limiting factor of this pilot study, the results obtained may pave the way for future studies to evaluate all the possible determinants of low protein consumption. The results related to the impact of low protein intake at each mealtime on muscle mass also indicate the importance of exploring this association in a larger sample population and, of course, considering other variables, such as physical activity, that could influence this relationship.

In general, the findings of this pilot study, together with previously published results, ${ }^{10}$ suggest that it may be necessary to design and implement dietetic and nutritional strategies aimed at improving protein consumption so as to achieve the quantities associated with prevention of loss of muscle mass and sarcopenia in this age group, which has a higher risk for deficient protein consumption. ${ }^{11}$ Intake of high quality protein, fast protein, a mixture of essential amino acids approximately equivalent to $30 \mathrm{~g}$ of protein twice or three times a day, and in particular branched chain amino acid supplementation, have been proposed as a nutrition strategy to counteract anabolic resistance and to stimulate protein synthesis in older adults. ${ }^{8,23-25}$
According to the results of this study, women showed the most significant differences in protein consumption, so this group could be the one that benefits most from increasing and improving their ingestion of dietary proteins. The findings of this study must be interpreted with caution due to the cross-sectional design. Finally, we recognize the limitations of the dietary method utilized to estimate total energy consumption and protein intake in a precise and accurate manner. With respect to the 24-hour diet recall method, we acknowledge that it has only limited reliability in this age group. ${ }^{26}$ In order to increase precision, we undertook three nonconsecutive 24-hour diet recalls (two during the week and the other in the weekend), and no subject had evidence of memory impairment. However, when aiming to improve the precision and accuracy of dietary methods, double-labeled water should be used as a gold standard technique to assess free-living energy expenditure in older adults.

\section{Conclusion}

On the basis of the results of this pilot study, we conclude that older adults do not receive the amount of dietary protein recommended to prevent sarcopenia. In addition, underconsumption of proteins per mealtime was found, with breakfast and dinner being the most compromised. A significant association was also found between protein consumption per mealtime and loss of muscle mass. Based on the results of this pilot study and those reported by other researchers, ${ }^{10}$ it would be convenient first to conduct more studies of representative samples and then to begin designing and implementing dietetic and nutritional strategies that will assure an adequate selection of protein-rich foods that are low in fats and will cover the recommended protein consumption to satisfy the objective of preserving muscle mass and preventing sarcopenia. Additional studies are required to evaluate the impact of a homogeneous increase and redistribution of dietary proteins on loss of muscle mass in older adults who are at greater risk of deficient dietary protein intake.

\section{Acknowledgments}

We thank the National Council on Science and Technology (CONACYT, 52466-M) and the Centro de Investigación en Alimentación y Desarrollo, AC, for the funding provided for this phase of the study. We are especially grateful to our volunteers and their families for their unconditional participation in the project.

\section{Disclosure}

The authors report no conflicts of interest in this work. 


\section{References}

1. Cruz-Jentoft AJ, Baeyens JP, Bauer JM, et al. Sarcopenia: European consensus on definition and diagnosis. Report of the European Working Group on Sarcopenia in Older People. Age Ageing. 2010;39(4): $412-423$.

2. Fielding RA, Vellas B, Evans WJ, et al. Sarcopenia: an undiagnosed condition in older adults. Current consensus definition: prevalence, etiology, and consequences. International Working Group on Sarcopenia. J Am Med Dir Assoc. 2011;12(4):249-256.

3. Scott D, Blizzard L, Fell J, Giles G, Jones G. Associations between dietary nutrient intake and muscle mass and strength in communitydwelling older adults: the Tasmanian Older Adult Cohort Study. J Am Geriat Soc. 2010;58(11):2129-2134.

4. Houston DK, Nicklas BJ, Ding J, et al. Dietary protein intake is associated with lean mass change in older, community-dwelling adults: the Health, Aging, and Body Composition (Health ABC) Study. Am J Clin Nutr. 2008;87(1):150-155.

5. Food and Agriculture Organization of the United Nations/World Health Organization/United Nations University. Energy and Protein Requirements: Report of a Joint FAO/WHO/UNU Expert Consultation. Geneva, Switzerland: World Health Organization; 1985. Available from: http://www.fao.org/docrep/003/aa040e/aa040e00.HTM. Accessed August 1, 2013.

6. Rand WM, Pellett PL, Young VR. Meta-analysis of nitrogen balance studies for estimating protein requirements in healthy adults. Am J Clin Nutr. 2003;77(1):109-127.

7. Morais JA, Chevalier S, Gougeon R. Protein turnover and requirements in the healthy and frail elderly. J Nutr Health Aging. 2006;10(4): 272-283.

8. Paddon-Jones D, Rasmussen BB. Dietary protein recommendations and the prevention of sarcopenia. Curr Opin Clin Nutr Metab Care. 2009;12(1):86-90.

9. Yang Y, Breen L, Burd NA, et al. Resistance exercise enhances myofibrillar protein synthesis with graded intakes of whey protein in older men. Br J Nutr. 2012;108(10):1780-1788.

10. Tieland M, Borgonjen-Van den Berg KJ, van Loon LJ, de Groot LC. Dietary protein intake in community-dwelling, frail, and institutionalized elderly people: scope for improvement. Eur J Nutr. 2012;51(2): 173-179.

11. Volpi E, Campbell WW, Dwyer JT, et al. Is the optimal level of protein intake for older adults greater than the recommended dietary allowance? J Gerontol A Biol Sci Med Sci. 2013;68(6):677-681.

12. Lawton MP, Brody EM. Assessment of older people: self-maintaining and instrumental activities of daily living. Gerontologist. 1969;9(3): 179-186.

13. Pfeiffer E. A short portable mental status questionnaire for the assessment of organic brain deficit in elderly patients. $J$ Am Geriatr Soc. $1975 ; 23(10): 433-441$.
14. Ortega M, Quizán T, Morales G, Preciado M. Food consumption and diet adequation analysis: 24 hours recall and food frequency questionnaires. Serie Evaluación del Consumo de Alimentos. 1999;1:1-48. Spanish.

15. Trumbo P, Schlicker S, Yates AA, Poos M. Dietary reference intakes for energy, carbohydrate, fiber, fat, fatty acids, cholesterol, protein and amino acids. J Am Diet Assoc. 2002;102(11):1621-1630.

16. Symons TB, Sheffield-Moore M, Wolfe RR, Paddon-Jones D. A moderate serving of high-quality protein maximally stimulates skeletal muscle protein synthesis in young and elderly subjects. J Am Diet Assoc. 2009;109(9):1582-1586.

17. Aleman Mateo H, Lee SY, Javed F, et al. Elderly Mexicans have less muscle and greater total and truncal fat compared with AfricanAmericans and Caucasians with the same BMI. J Nutr Health Aging. 2009;13(10):919-923.

18. Heymsfield SB, Smith R, Aulet M, et al. Appendicular skeletal muscle mass: measurement by dual-photon absorptiometry. Am J Clin Nutr. 1990;52(2):214-218.

19. Hansen RD, Raja C, Aslani A, Smith RC, Allen BJ. Determination of skeletal muscle and fat-free mass by nuclear and dual-energy $\mathrm{x}$-ray absorptiometry methods in men and women aged 51-84 y (1-3). Am J Clin Nutr. 1999;70(2):228-233.

20. US Department of Agriculture, Agricultural Research Service. Data Tables: Results from USDA's 1996 Continuing Survey of Food Intakes by Individuals and 1996 Diet and Health Knowledge Survey. 1997. Available from: http://www.barc.usda.gov/bhnrc/foodsurvey/home. htm. Accessed December 5, 2012.

21. Alemán H, Esparza J, Ramirez FA, Astiazaran H, Payette H. Longitudinal evidence on the association between interleukin- 6 and C-reactive protein with the loss of total appendicular skeletal muscle in free-living older men and women. Age Ageing. 2011;40(4):469-475.

22. Alemán-Mateo H, Salazar G, Hernández-Triana M, Valencia M. Total energy expenditure, resting metabolic rate and physical activity level in free-living rural elderly men and women from Cuba, Chile and Mexico. Eur J Clin Nutr. 2006;60(11):1258-1265.

23. Børsheim E, Bui QU, Tissier S, Kobayashi H, Ferrando AA, Wolfe RR. Effect of amino acid supplementation on muscle mass, strength and physical function in elderly. Clin Nutr. 2008;27(2):189-195.

24. Paddon-Jones D, Sheffield-Moore M, Zhang XJ, et al. Amino acid ingestion improves muscle protein synthesis in the young and elderly. Am J Physiol Endocrinol Metab. 2004;286(3):E321-E328.

25. Boirie Y. Physiopathological mechanism of sarcopenia. J Nutr Health Aging. 2009;13(8):717-723.

26. Sun Y, Roth DL, Ritchie CS, Burgio KL, Locher JL. Reliability and predictive validity of energy intake measures from the 24-hour dietary recalls of homebound older adults. J Am Diet Assoc. 2010;110(5): $773-778$.
Clinical Interventions in Aging

\section{Publish your work in this journal}

Clinical Interventions in Aging is an international, peer-reviewed journal focusing on evidence-based reports on the value or lack thereof of treatments intended to prevent or delay the onset of maladaptive correlates of aging in human beings. This journal is indexed on PubMed Central, MedLine, the American Chemical Society's 'Chemical Abstracts
Dovepress

Service' (CAS), Scopus and the Elsevier Bibliographic databases. The manuscript management system is completely online and includes a very quick and fair peer-review system, which is all easy to use. Visit $\mathrm{http}: / /$ www.dovepress.com/testimonials.php to read real quotes from published authors. 